\title{
MODELING OF SOLAR RADIATION AVAILABLE AT DIFFERENT ORIENTATIONS OF GREENHOUSES
}

\author{
SAMIR AHMAD ALI*
}

\begin{abstract}
This study presents a model development to determine the optimum orientation of a greenhouse for year round applications under different climatic conditions. The most commonly structural form used in the study is gable-even-span single type greenhouse with different orientations. Total solar radiation flux incident on each wall, included vertical surfaces and inclined roofs, was computed for solar greenhouse orientations and compared for January and July months of the year at the northern hemisphere. Model validation was executed for the measured global solar radiation data on a horizontal surface at the Faculty of Agriculture, Toukh, Qalubia, Egypt $\left(30.36^{\circ} \mathrm{N}, 31.22^{\circ} \mathrm{E}\right.$ and altitude $15 \mathrm{~m}$,. The obtained results showed that, the predicted and measured values are in close agreement. Results also revealed that, the orientation of east-west $(E)$ and south-north $(S)$ of gable even-span solar greenhouse, respectively, was the best suited during January and July months.
\end{abstract}

Key words: solar greenhouse, orientation, solar energy

\section{INTRODUCTION}

The main purpose of a greenhouse construction is to provide an
optimal level of microclimatic conditions for plant growth,
development, and productivity on a year-round basis or to extend the growing season. The environment inside a greenhouse is dependent on many factors including; time of the year, amount and duration of natural sunlight, the air relative humidity, the size and type of equipment, structural frame, and type of plants growing in the house. Total solar radiation received by a greenhouse at a particular time and locations depends upon its structural frame, orientation, covering material, and surrounding topography, which ultimately determines the inside air

\footnotetext{
*Agric. Eng. Dept., Fac. Agric., Moshtohor, Toukh, Qalubia, P.O. Box, 13736, Egypt.

Phone: +2 $0132467034 \quad$ Fax: +2 0132467786

E-Mail samir.ali@fagr.bu.edu.eg
} 
temperature. The inside air temperature of a passive greenhouse is directly dependent upon the ambient air temperature, solar radiation intensity, overall heat transfer coefficient, covering material, and wind speed and its direction. Indoor air temperature is one of the most dominant parameters affecting the plant growth, development, and productivity (Sethi and Sharma, 2007).

Various research works have been used different structural frames of greenhouses at different latitudes for raising off-season vegetables and ornamental plants around the world. These greenhouses are orientated on east-west (EW) or north-south (NS) orientation (longitudinal direction). It is observed that, the most commonly forms of greenhouses used for the agriculture applications are; gable-even-span, gable-uneven-span, vinery, modified Quonset, and Quonset type. Sethi (2009) compared between different forms of greenhouses in order to select the most suitable form and showed that gable-uneven-span form greenhouse receives the maximum solar radiation during all months of the year for different climatic zones. Tavares et al. (2001) discussed the specific climate problems of the utilizations of greenhouses in Portugal, during winter and summer days and revealed that, the necessity of having a tool capable of predicting the thermal behavior of a greenhouse under specific exterior conditions. Beshada et al. (2004) analyzed the thermal performance of a solar greenhouse, orientated due south to absorb the maximum possible solar energy, and had a north wall to store solar energy at daytime. It has been efficiently used in China to grow vegetables and flowers during the wintertime, under cold weather conditions. Kumari et al. (2007) determined the performance of different forms of greenhouses, with equal floor surface area as well as the central height, for five different climatic zones of India. Impron et al. (2007) developed a greenhouse climatic model to optimize cover properties and ventilation rates for the tropical lowlands of Indonesia. Pieters et al. (2000) developed threedimensional numerical model for the simulation of the solar radiation transmittance and distribution in any single or multi-span greenhouse with vertical walls and flat roof planes. Saravia et al. (1997) discussed greenhouse solar heating in the Argentinean north-west in order to 
increase the nightly average temperature and avoid freezing problems inside the greenhouses, for local meteorological conditions.

The selection of optimum orientation of a greenhouse can cause some reduction in the heating loads of the installed systems thereby saving a lot of cost. In this study, an attempt has been made to select the orientation of greenhouse on the basis of total solar radiation available. The main objective of this work is to develop a model for solar radiation available on the cover of the greenhouse with different orientations.

\section{Total solar radiation available on greenhouse cover}

A single layer polyethylene greenhouse, gable-even-span form, is selected for this study at any orientation (Fig. 1). Gable-even-span form greenhouse receives the maximum possible solar radiation during each month of the year with eight different orientations. Length, width, and height of greenhouse, respectively, are $40 \mathrm{~m}, 8 \mathrm{~m}$, and $3 \mathrm{~m}$. Greenhouse is divided into a six various sections with any orientation.

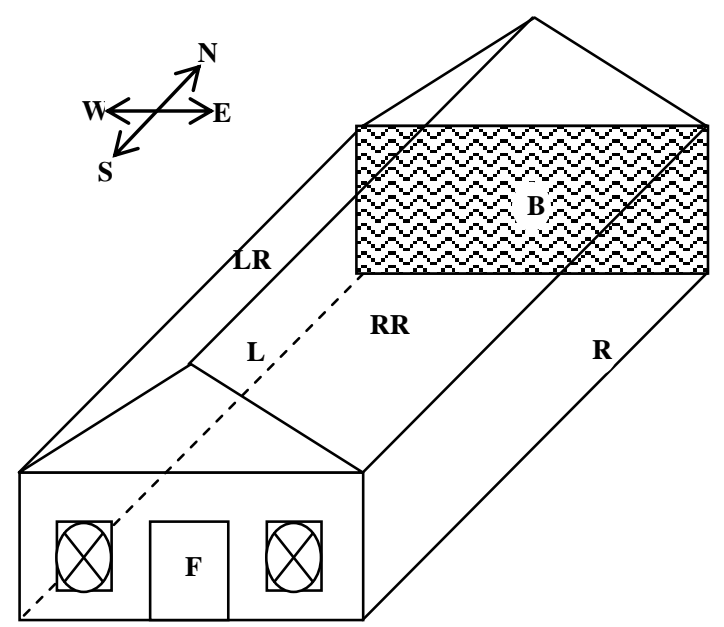

Fig. (1): Schematic diagram of gable-even-span greenhouse

Model development:

There are three assumptions for the model calculations as follows:

(1) Modeling of solar radiation being a complex one, greenhouse was divided into six sections to simplify the process. Number of sections 
( $F$ is front wall, $B$ is back wall, $R$ is right wall, $L$ is left wall, $R R$ is right roof, and $L R$ is left roof) are equal to the number of walls and roofs of the greenhouse in different planes. The details of each section are shown in Table (1).

(2) South (S) oriented door of greenhouse (section F) is considered at 0 。 orientation and any positive orientation is considered in clockwise direction to north and vice versa.

(3) Calculations have been done under clear sky conditions.

Table (1): Sectional details of geometry greenhouses

\begin{tabular}{|c|c|c|c|c|c|c|c|c|}
\hline \multicolumn{3}{|l|}{ Section Name } & $\mathrm{F}$ & $\mathrm{B}$ & $\mathrm{R}$ & $\mathrm{L}$ & RR & LR \\
\hline \multirow{2}{*}{$\begin{array}{l}\text { Section Area } \\
\mathrm{m}^{2}\end{array}$} & \multicolumn{2}{|c|}{ With Pad and Fan } & 24.8 & 6.8 & 120.0 & 120.0 & 173.8 & 173.8 \\
\hline & \multicolumn{2}{|c|}{ Without Pad and Fan } & 28.8 & 30.8 & 120.0 & 120.0 & 173.8 & 173.8 \\
\hline \multicolumn{3}{|l|}{ Tilt Angle $(\Sigma)$} & 90 & 90 & 90 & 90 & 25 & 25 \\
\hline \multirow{8}{*}{\multicolumn{2}{|c|}{$\begin{array}{l}\text { Surface Azimuth } \\
\qquad(\Psi)\end{array}$}} & S Orientation & 0 & 180 & -90 & 90 & -90 & 90 \\
\hline & & SE Orientation & -45 & 135 & -135 & 45 & -135 & 45 \\
\hline & & E Orientation & -90 & 90 & 180 & 0 & 180 & 0 \\
\hline & & EN Orientation & -135 & 45 & 135 & -45 & 135 & -45 \\
\hline & & N Orientation & 180 & 0 & 90 & -90 & 90 & -90 \\
\hline & & NW Orientation & 135 & -45 & 45 & -135 & 45 & -135 \\
\hline & & W Orientation & 90 & -90 & 0 & 180 & 0 & 180 \\
\hline & & SW Orientation & 45 & -135 & -45 & 135 & -45 & 135 \\
\hline
\end{tabular}

The total solar radiation flux incident $(\mathrm{E})$ on a surface is the combination of the direct (subscript D), diffuse (subscript d) and ground-reflected (subscript r) irradiance of the surface (ASHRAE, 2005), which gives (ASHRAE, 2005):

$$
E_{t}=E_{D}+E_{d}+E_{r}
$$

The amount of solar irradiance is computed based on a number of solar angles and apparent solar time. Apparent solar time (AST) is, in decimal hours:

$$
A S T=L S T+\frac{E T}{60}+\frac{L S M-L O N}{15}
$$

Where:

$$
\text { LST = local standard time, decimal hours }
$$


ET = equation of time, decimal minutes

LSM = local standard time meridian, decimal degrees.

LON = local longitude, decimal degree.

The equation of time as taken from Duffie and Beckman (1991) is:

$$
\begin{aligned}
\text { ET }=229.2\{ & 0.000075+0.001868 \cos \left[(\eta-1) \frac{360}{365}\right]-0.032077 \sin [(\eta \\
& -1) 360 / 365]-0.014615 \cos 2[(\eta-1) 360 / 365] \\
& -0.04089 \sin 2[(\eta-1) 360 / 365]\}
\end{aligned}
$$

Where $\eta$ is the number of the day from the first of January (where January $1^{\text {st }}$ is $\eta=1$ )

The solar altitude $(\beta)$ can be calculated as:

$$
\sin \beta=\cos L \cos \delta \cos H+\sin L \sin \delta
$$

Where:

$\mathrm{L} \quad=$ latitude angle, degrees

$\delta=$ solar declination angle, degrees

$$
\delta=23.45 \sin \left\{\frac{[360(284-\eta)]}{365}\right\}
$$

$\mathrm{H}=$ solar hour angle, degrees

$$
H=15(A S T-12)
$$

The solar incident angle $(\theta)$ can be computed as:

$$
\cos \theta=\cos \beta \cos \gamma \sin \Sigma+\sin \beta \cos \Sigma
$$

Where:

$$
\begin{aligned}
& \Sigma \quad=\text { surface tilt angle from the horizontal plane, horizontal }=0^{\circ} \\
& \gamma \quad=\text { surface-solar azimuth angle } \\
& \gamma=\phi-\Psi \\
& \varphi \quad=\text { solar azimuth angle } \\
& \cos \phi=\frac{\sin \beta \sin L-\sin \delta}{\cos \beta \cos L} \\
& \Psi \quad=\text { surface azimuth angle, degrees }
\end{aligned}
$$


A computer program has been prepared in MS Excel to calculate these angles. The value of these angles on typical day of January and July has been given in Table (2).

Table (2): The position of the sun on place in question

\begin{tabular}{|c|c|c|c|c|c|c|c|c|c|c|c|c|}
\hline \multirow[b]{2}{*}{$\begin{array}{l}\text { Solar } \\
\text { Time } \\
\text { AST }\end{array}$} & \multicolumn{6}{|c|}{ January, 17} & \multicolumn{6}{|c|}{ July, 17} \\
\hline & $\begin{array}{c}\text { Hour } \\
\text { Angle } \\
\mathrm{H}\end{array}$ & $\begin{array}{c}\text { Solar } \\
\text { Altitud } \\
\text { e } \\
\beta\end{array}$ & $\begin{array}{c}\text { Zenith } \\
\text { Angle } \\
\text { Z }\end{array}$ & $\begin{array}{c}\text { Solar } \\
\text { Azimu } \\
\text { th } \\
\text { Ф }\end{array}$ & $\begin{array}{l}\text { Tilt } \\
\text { Angle } \\
\Sigma\end{array}$ & $\begin{array}{c}\text { Incide } \\
\text { nce } \\
\text { Angle } \\
\theta\end{array}$ & $\begin{array}{c}\text { Hour } \\
\text { Angle } \\
\mathrm{H}\end{array}$ & $\begin{array}{c}\text { Solar } \\
\text { Altitud } \\
\text { e } \\
\beta\end{array}$ & $\begin{array}{c}\text { Zenith } \\
\text { Angle } \\
\text { Z }\end{array}$ & $\begin{array}{c}\text { Solar } \\
\text { Azimu } \\
\text { th } \\
\Phi\end{array}$ & $\begin{array}{l}\text { Tilt } \\
\text { Angle } \\
\Sigma\end{array}$ & $\begin{array}{c}\text { Incide } \\
\text { nce } \\
\text { Angle } \\
\theta\end{array}$ \\
\hline $1: 00 \mathrm{AM}$ & -165.00 & -73.53 & 163.53 & -121.47 & 163.53 & 163.53 & -165.00 & -36.48 & 126.48 & -162.53 & 126.48 & 126.48 \\
\hline $2: 00 \mathrm{AM}$ & -150.00 & -61.46 & 151.46 & -102.18 & 151.46 & 151.46 & -150.00 & -30.94 & 120.94 & -147.07 & 120.94 & 120.94 \\
\hline 3:00 AM & -135.00 & -48.62 & 138.62 & -92.24 & 138.62 & 138.62 & -135.00 & -22.72 & 112.72 & -134.37 & 112.72 & 112.72 \\
\hline 4:00 AM & -120.00 & -35.69 & 125.69 & -84.91 & 125.69 & 125.69 & -120.00 & -12.69 & 102.69 & -124.14 & 102.69 & 102.69 \\
\hline 5:00 AM & -105.00 & -22.90 & 112.90 & -78.36 & 112.90 & 112.90 & -105.00 & -1.47 & 91.47 & -115.72 & 91.47 & 91.47 \\
\hline 6:00 AM & -90.00 & -10.40 & 100.40 & -71.75 & 100.40 & 100.40 & -90.00 & 10.52 & 79.48 & -108.49 & 79.48 & 79.48 \\
\hline 7:00 AM & -75.00 & 1.61 & 88.39 & -64.51 & 88.39 & 88.39 & -75.00 & 23.01 & 66.99 & -101.90 & 66.99 & 66.99 \\
\hline $8: 00 \mathrm{AM}$ & -60.00 & 12.86 & 77.14 & -56.07 & 77.14 & 77.14 & -60.00 & 35.80 & 54.20 & -95.39 & 54.20 & 54.20 \\
\hline 9:00 AM & -45.00 & 22.92 & 67.08 & -45.82 & 67.08 & 67.08 & -45.00 & 48.73 & 41.27 & -88.14 & 41.27 & 41.27 \\
\hline $10: 00 \mathrm{AM}$ & -30.00 & 31.17 & 58.83 & -33.08 & 58.83 & 58.83 & -30.00 & 61.57 & 28.43 & -78.33 & 28.43 & 28.43 \\
\hline 11:00 AM & -15.00 & 36.73 & 53.27 & -17.56 & 53.27 & 53.27 & -15.00 & 73.70 & 16.30 & -59.28 & 16.30 & 16.30 \\
\hline 12:00 PM & 0.00 & 38.72 & 51.28 & 0.00 & 51.28 & 51.28 & 0.00 & 80.82 & 9.18 & 0.00 & 9.18 & 9.18 \\
\hline 1:00 PM & 15.00 & 36.73 & 53.27 & 17.56 & 53.27 & 53.27 & 15.00 & 73.70 & 16.30 & 59.28 & 16.30 & 16.30 \\
\hline 2:00 PM & 30.00 & 31.17 & 58.83 & 33.08 & 58.83 & 58.83 & 30.00 & 61.57 & 28.43 & 78.33 & 28.43 & 28.43 \\
\hline 3:00 PM & 45.00 & 22.92 & 67.08 & 45.82 & 67.08 & 67.08 & 45.00 & 48.73 & 41.27 & 88.14 & 41.27 & 41.27 \\
\hline 4:00 PM & 60.00 & 12.86 & 77.14 & 56.07 & 77.14 & 77.14 & 60.00 & 35.80 & 54.20 & 95.39 & 54.20 & 54.20 \\
\hline 5:00 PM & 75.00 & 1.61 & 88.39 & 64.51 & 88.39 & 88.39 & 75.00 & 23.01 & 66.99 & 101.90 & 66.99 & 66.99 \\
\hline 6:00 PM & 90.00 & -10.40 & 100.40 & 71.75 & 100.40 & 100.40 & 90.00 & 10.52 & 79.48 & 108.49 & 79.48 & 79.48 \\
\hline 7:00 PM & 105.00 & -22.90 & 112.90 & 78.36 & 112.90 & 112.90 & 105.00 & -1.47 & 91.47 & 115.72 & 91.47 & 91.47 \\
\hline 8:00 PM & 120.00 & -35.69 & 125.69 & 84.91 & 125.69 & 125.69 & 120.00 & -12.69 & 102.69 & 124.14 & 102.69 & 102.69 \\
\hline 9:00 PM & 135.00 & -48.62 & 138.62 & 92.24 & 138.62 & 138.62 & 135.00 & -22.72 & 112.72 & 134.37 & 112.72 & 112.72 \\
\hline 10:00 PM & 150.00 & -61.46 & 151.46 & 102.18 & 151.46 & 151.46 & 150.00 & -30.94 & 120.94 & 147.07 & 120.94 & 120.94 \\
\hline 11:00 PM & 165.00 & -73.53 & 163.53 & 121.47 & 163.53 & 163.53 & 165.00 & -36.48 & 126.48 & 162.53 & 126.48 & 126.48 \\
\hline
\end{tabular}

Now the equations of solar irradiance are computed based on all of these angles in the following manner. The surface direct irradiance:

$$
\text { If } \cos \theta>0 \stackrel{\text { then }}{\longrightarrow} E_{D}=E_{D N} \cos \theta_{0} \stackrel{\text { otherwise }}{\longrightarrow} E_{D}=0
$$

And where ${\left(E_{D N}\right)}$ is the surface direct irradiance and is calculated as:

$$
\text { If } \beta>0 \stackrel{\text { then }}{\longrightarrow} E_{D N}=\frac{A}{\operatorname{EXP}(B / \sin \beta)} \stackrel{\text { otherwise }}{\longrightarrow} E_{D N}=0
$$

The diffuse irradiance $E_{d}$

For vertical surfaces

$$
E_{d}=C Y E_{D N}
$$


For surfaces other than vertical $\quad E_{d}=C Y E_{D N} \frac{(1+\cos \Sigma)}{2}$

Where $\mathrm{Y}$ is the ratio of the sky diffuse irradiation on a vertical surfaces to the sky diffuse irradiation on a horizontal surfaces and

If $\cos (\theta)>-0.2 Y=0.55+0.437 \cos (\theta)+0.313 \cos ^{2}(\theta)$, otherwise $\mathrm{Y}=0.45$

Finally, the ground-reflected irradiance $E_{r}$ is computed as:

$$
E_{r}=E_{D N}\left(C_{n}+\sin \beta\right) \rho_{g}\left(\frac{1-\cos \Sigma}{2}\right)
$$

Where:

$$
\begin{aligned}
& \begin{array}{r}
\mathrm{A}=\text { apparent solar radiation, } \mathrm{W} \mathrm{m}^{-2} \\
\quad= \\
\mathrm{B}=\text { atmospheric extinction coefficient } \\
\quad=0.1639+0.0237 \times \sin (0.0202 \times \eta+4.013)
\end{array} \\
& \begin{array}{r}
\mathrm{C}=\text { sky diffuse factor } \\
\quad=0.1207+0.0179 \times \sin (0.0203 \times \eta+3.9798)
\end{array} \\
& \begin{array}{r}
\mathrm{C}_{\mathrm{n}}=\text { clearness number } \\
\rho_{g}=\text { ground reflectivity, often taken to be } 0.2 \text { for typical mixture }
\end{array} \\
& \text { of ground surfaces. }
\end{aligned}
$$

The hourly total solar radiation flux incident on different inclined and vertical surfaces of the greenhouse is the total sum of solar radiation falling on different surfaces (each wall and roof) of the greenhouse. Total solar radiation falling on tilted surface of the greenhouse has been computed on an hourly basis for all the sections of each form of the greenhouse with eight different orientations, using the above equations and data from Table (1). Total solar radiation available on the greenhouse cover is thus given by:

$$
S_{t}=\sum_{i=1}^{6} A_{i} E_{i}
$$


Where $A_{\mathrm{i}}$ and $E_{i}$ are the surface area of the $i^{\text {th }}$ section and the total solar radiation $\left(\mathrm{W} \mathrm{m}^{-2}\right)$ available on $i^{\text {th }}$ section $i$. e. for any orientation the hourly total solar radiation is given by:

$$
S_{t}=A_{F} E_{F}+A_{B} E_{B}+A_{R} E_{R}+A_{L} E_{L}+A_{R R} E_{R R}+A_{L R} E_{L R}
$$

Where $F$ is front wall, $B$ is back wall, $R$ is right wall, $L$ is left wall, $R R$ is right roof, and $L R$ is left roof. The hourly total solar radiation flux incident on greenhouse cover surfaces is calculated for the average day of July (17) and January (17) at Faculty of Agriculture, Toukh, Qalubia, Egypt $\left(30.36^{\circ} \mathrm{N}, 31.22^{\circ} \mathrm{E}\right.$ and altitude $\left.15 \mathrm{~m}\right)$.

\section{Model validation}

Model validation is carried out for the measured data of solar radiation at the specific location. Daily average global solar radiation data measured on the horizontal surface is compared with that theoretically computed on the same surfaces for the day average of January month (17) as revealed in Fig. (2), and for the average day of July month (17) as shown in Fig. (3). It is observed that both the set of values are closely matched indicating that the developed model is validated well.

\section{RESULTS AND DISCUSSION}

A comparison between the total solar radiation available on the selected two days of January and July months with different eight orientations is shown in Figs. (4 and 5) and listed in Table (3).

With S-E orientation: it can be observed that, the highest total solar radiation $\left(926.9 \mathrm{~W} \mathrm{~m}^{-2}\right)$ was achieved on the front surface $(\mathrm{F})$ at 12:00 noon during January month, while the lowest value $\left(115 \mathrm{~W} \mathrm{~m}^{-2}\right)$ was obtained at the same time on the back wall of the greenhouse cover during January month.

Front wall of the greenhouse collected $926.9 \mathrm{~W} \mathrm{~m}^{-2}$ at 12:00 noon and as low as $4.13 \mathrm{~W} \mathrm{~m}^{-2}$ at 8:00 am with daily total solar radiation of $6527.96 \mathrm{~W}$

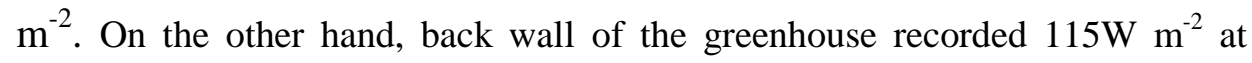
12:00 noon as minimum with daily total St of $800.22 \mathrm{~W} \mathrm{~m}^{-2}$. 


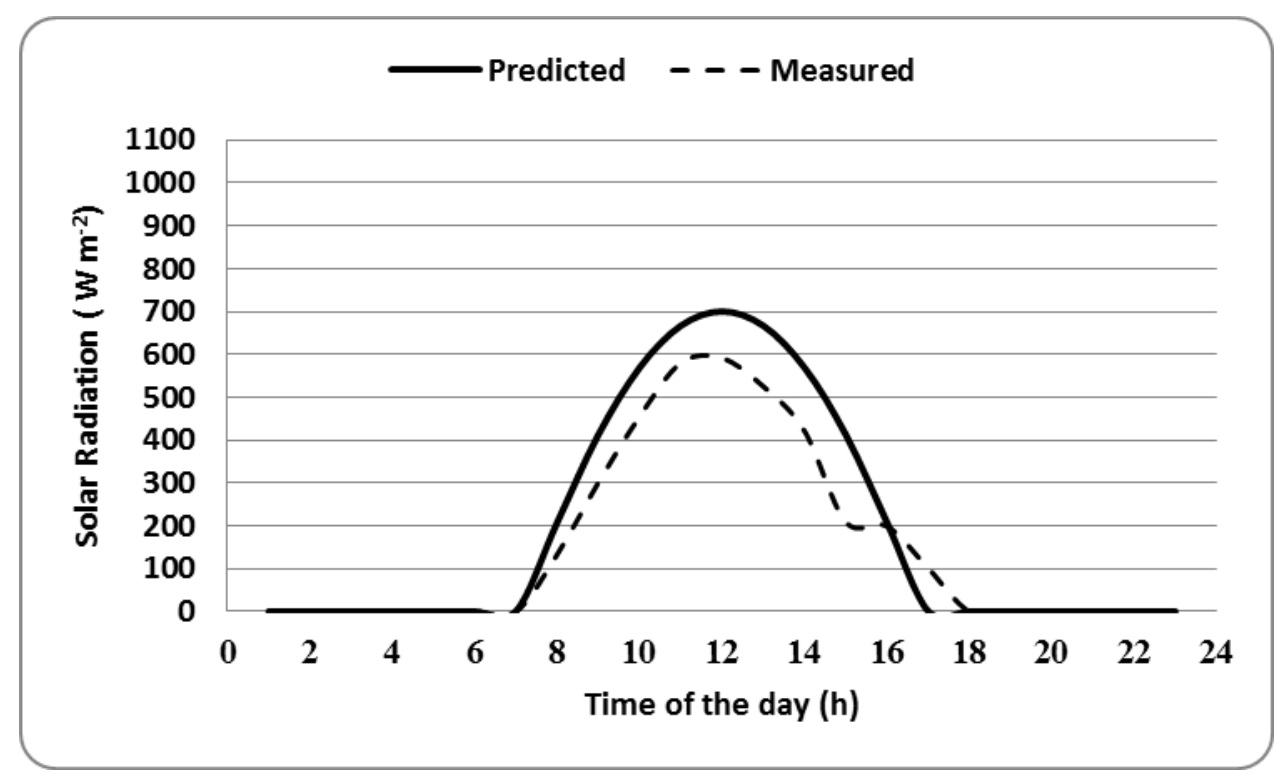

Fig.(2): Daily average solar radiation on the horizontal surface for the average day of January month.

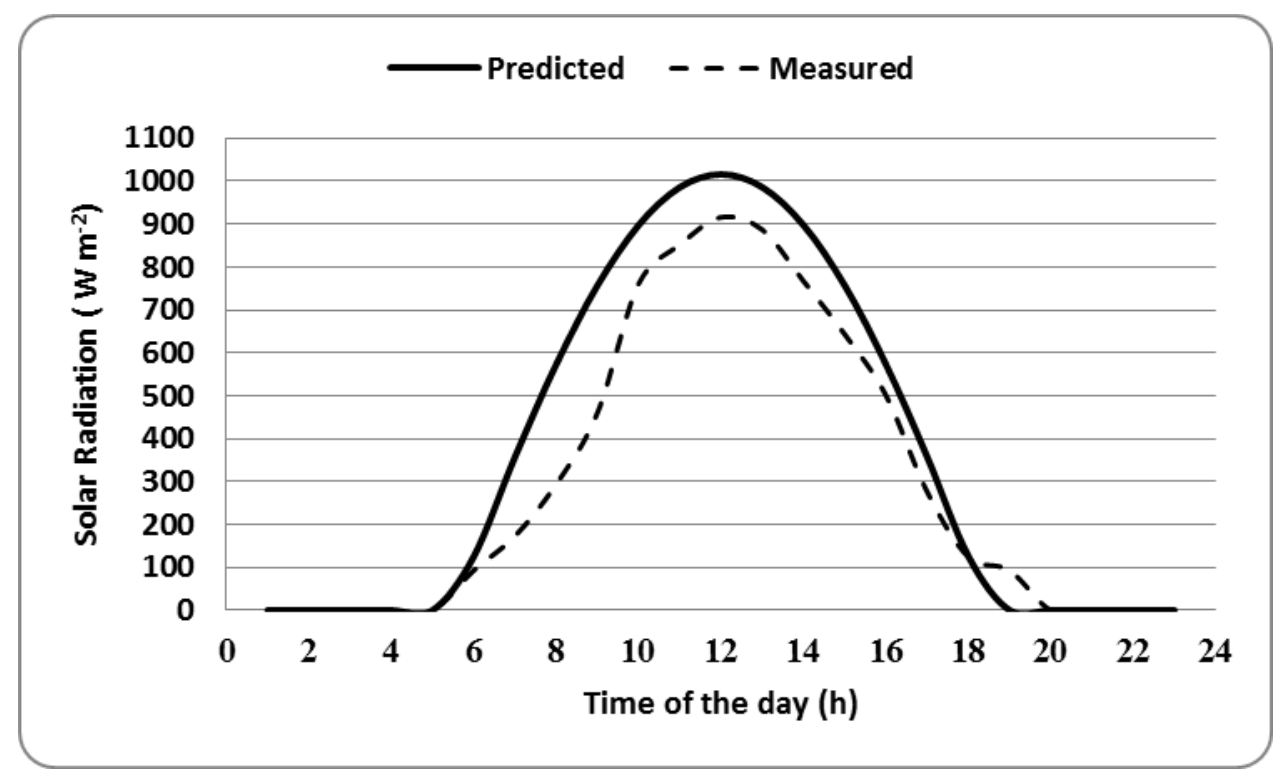

Fig. (3): Daily average solar radiation on the horizontal surface for the average day of July month. 


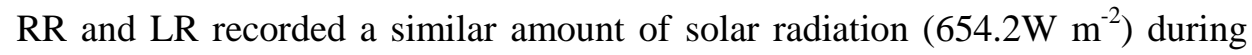
the same time (12:00noon) with daily total solar radiation of $4205.71 \mathrm{~W} \mathrm{~m}^{-2}$.

With S-E orientation, on January month, the front (F) and left (L) walls recorded similar amount of daily solar radiation $\left(5015.57 \mathrm{~W} \mathrm{~m} \mathrm{~m}^{-2}\right.$ ). It could be noticed that the left roof side (LR) obtained the highest amount of daily solar radiation $\left(5593.8 \mathrm{~W} \mathrm{~m}^{-2}\right)$, while the left roof side (LR) received about the half of this amount $\left(2783.02 \mathrm{~W} \mathrm{~m}^{-2}\right)$. It is worthily to notice that both back and right walls received the same amount of daily solar radiation (958.42 $\mathrm{W} \mathrm{m}^{-2}$ ) which was the lowest amount as compared with those recorded for the other sides and covers under this orientation, at the same time.

Regarding the $\mathrm{E}$ orientation during January month, the highest daily solar radiation was $6527.96 \mathrm{~W} \mathrm{~m} \mathrm{~m}^{-2}$ for the left wall of the greenhouse, while the lowest value of daily solar radiation $\left(800.22 \mathrm{~W} \mathrm{~m}^{-2}\right)$ was received by the right wall. The orientation of $\mathrm{E}-\mathrm{N}$ received the highest daily radiation $\left(5593.84 \mathrm{~W} \mathrm{~m}^{-2}\right)$ on the left roof, while both right and front walls received the lowest values $\left(958.42 \mathrm{~W} \mathrm{~m}^{-2}\right)$. The daily solar radiation received with the $\mathrm{N}$ orientation, was found on the back wall which received the highest value $\left(6527.96 \mathrm{~W} \mathrm{~m} \mathrm{~m}^{-2}\right)$, while, the front wall had the lowest value $\left(800.22 \mathrm{~W} \mathrm{~m}^{-2}\right)$. It is very useful to notice that both $\mathrm{R}$ and $\mathrm{L}$ walls received the same amount of solar radiation $\left(2689.87 \mathrm{~W} \mathrm{~m}^{-2}\right)$, also $\mathrm{RR}$ and LR received similar quantities of solar radiation $\left(4205.7 \mathrm{~W} \mathrm{~m}^{-2}\right)$.

With N-W orientation, the maximum daily solar radiation $\left(5593.84 \mathrm{~W} \mathrm{~m}^{-2}\right)$ was received by the RR wall of the greenhouse, while the lowest values of daily solar radiation were received by the front and left side walls of the greenhouse. Both back and right walls received the same amount of daily solar radiation $\left(5015.6 \mathrm{~W} \mathrm{~m} \mathrm{~m}^{-2}\right)$.

With $\mathrm{W}$ orientation, it could be seen that the $\mathrm{R}$ wall received the highest daily solar radiation $\left(6527.96 \mathrm{~W} \mathrm{~m}^{-2}\right)$, while the left wall received the lowest value of daily solar radiation $\left(800.22 \mathrm{~W} \mathrm{~m}^{-2}\right)$. It is clear that, the front and the back walls received the same amount of daily solar radiation (2689.87W m²).

Concerning the daily solar radiation received by the different locations of the greenhouse with orientation of S-W, it was found that, the RR side received the highest daily solar radiation $\left(5593.84 \mathrm{~W} \mathrm{~m}^{-2}\right)$, while both back and left walls received the lowest values $\left(958.4 \mathrm{~W} \mathrm{~m}^{-2}\right)$. 


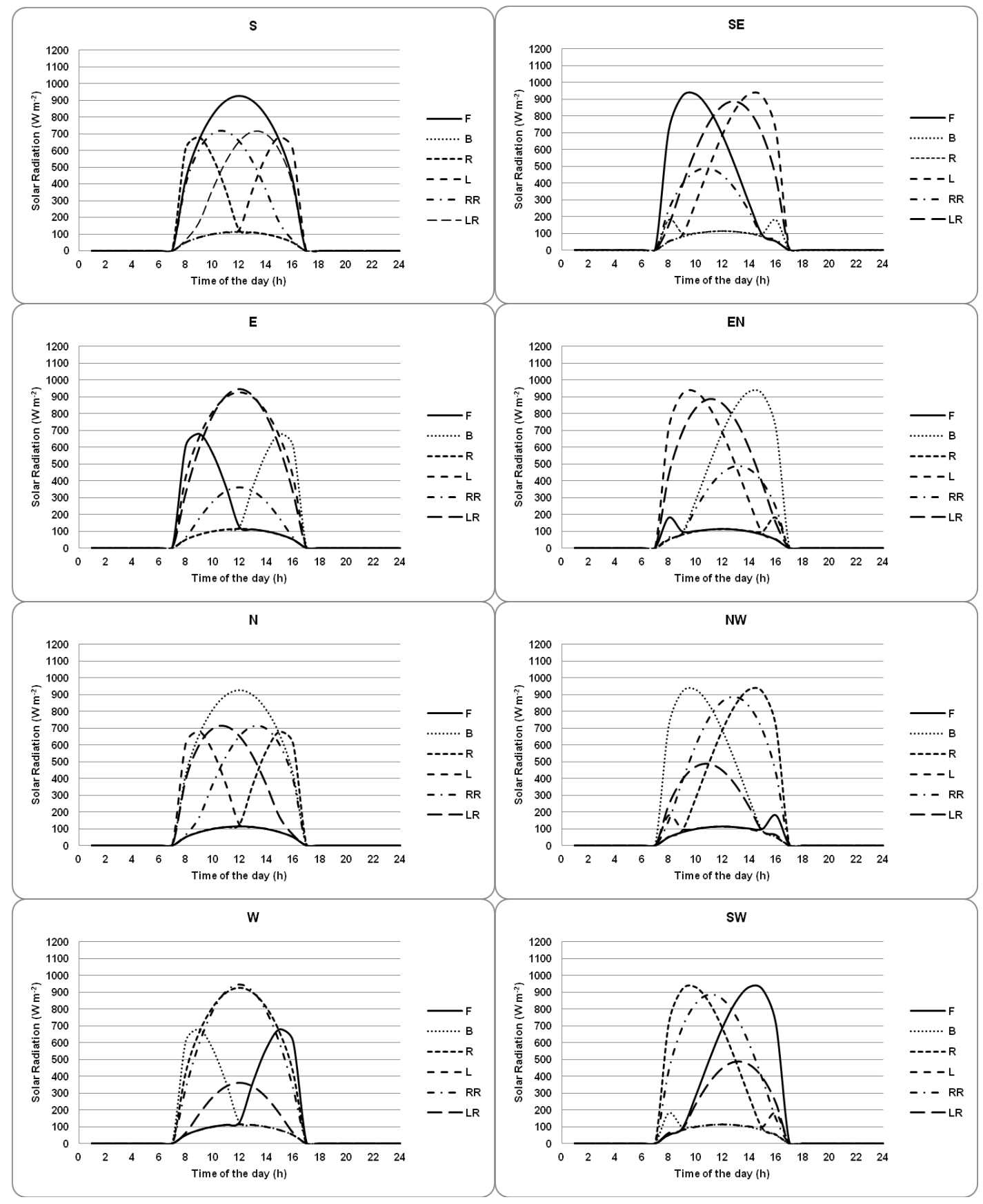

Fig. (4): Hourly variation of the total solar intensity on different walls and roofs of with different eight orientations of greenhouses during January month. 


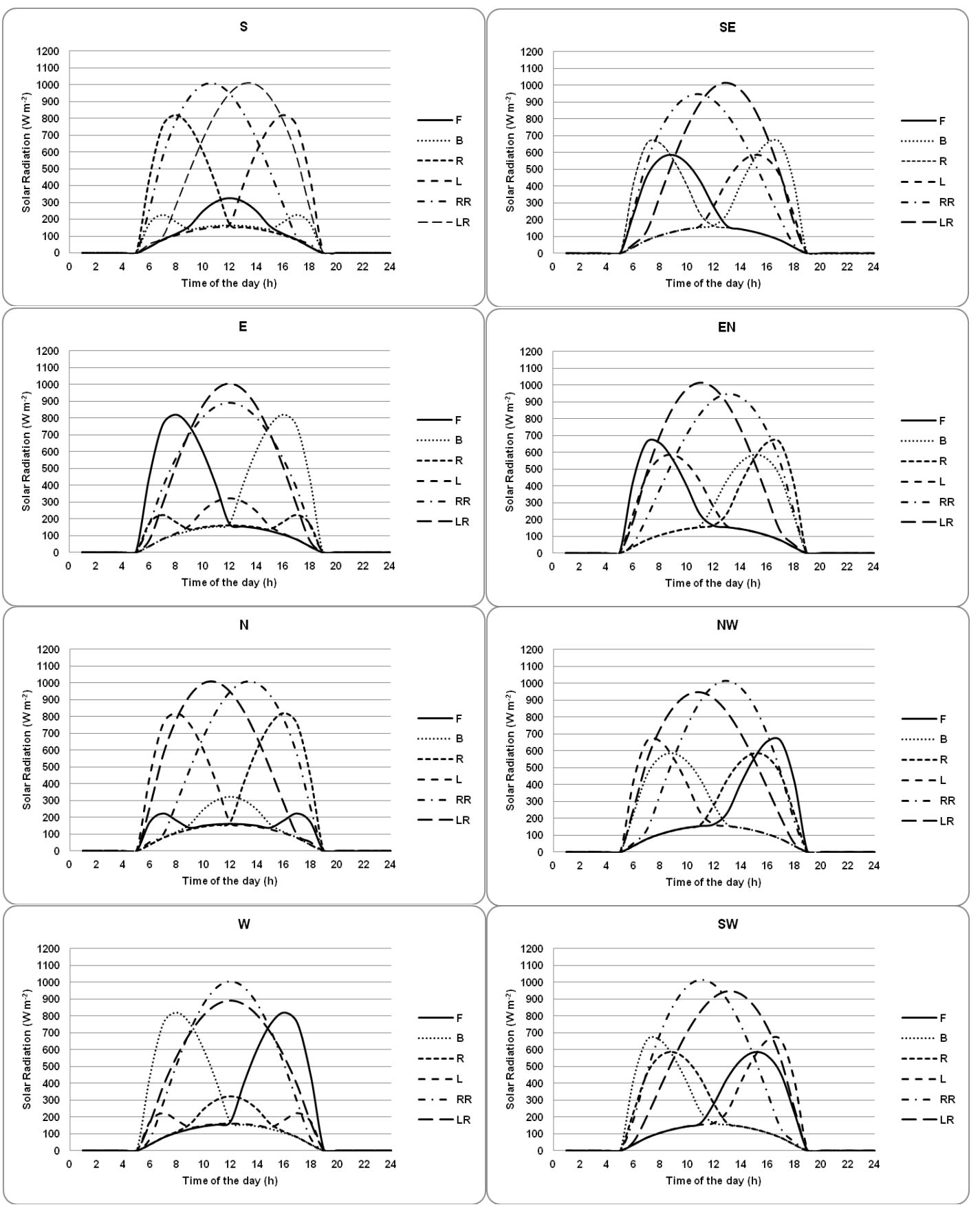

Fig. (5): Hourly variation of the total solar intensity on different walls and roofs with different eight orientations of greenhouses during July month. 
Table: (3). Total solar radiation on different walls and roofs of even span for eight orientations greenhouse for a typical winter and summer day (January, 17 and July, 17).

\begin{tabular}{|c|c|c|c|c|c|c|c|c|c|c|c|c|c|c|c|}
\hline \multirow{4}{*}{ 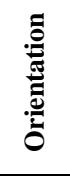 } & \multirow{2}{*}{ SURFACE: } & \multicolumn{7}{|c|}{ January, 17} & \multicolumn{7}{|c|}{ July, 17} \\
\hline & & $\mathbf{F}$ & $\mathbf{B}$ & $\mathbf{R}$ & $\mathbf{L}$ & $\mathbf{R R}$ & LR & Total & $\mathbf{F}$ & $\mathbf{B}$ & $\mathbf{R}$ & $\mathbf{L}$ & $\mathbf{R R}$ & LR & Total \\
\hline & Area $\left(\mathrm{m}^{2}\right)$ & 24.79 & 6.79 & 120.00 & 120.00 & 173.82 & 173.82 & 619.22 & 24.79 & 6.79 & 120.00 & 120.00 & 173.82 & 173.82 & 619.22 \\
\hline & Tilt angle $(\Sigma)$ & 90 & 90 & 90 & 90 & 23 & 23 & & 90 & 90 & 90 & 90 & 23 & 23 & \\
\hline \multirow{3}{*}{$\mathbf{S}$} & Azimuth angle ( $\Psi)$ & $\mathbf{0}$ & 180 & -90 & 90 & -90 & 90 & & $\mathbf{0}$ & 180 & -90 & 90 & -90 & 90 & \\
\hline & Solar Radiation $\left(\mathrm{W} \mathrm{m}^{-2}\right)$ & 6527.96 & 800.22 & 2689.87 & 2689.87 & 4205.71 & 4205.71 & & 2210.13 & 2224.48 & 4590.03 & 4590.03 & 7939.77 & 7939.77 & \\
\hline & Total Solar Radiation (kW) & 161.84 & 5.43 & 322.78 & 322.78 & 731.03 & 731.03 & 2274.90 & 54.79 & 15.11 & 550.80 & 550.80 & 1380.07 & 1380.07 & 3931.65 \\
\hline \multirow{3}{*}{ SE } & Azimuth angle ( $\Psi)$ & -45 & 135 & -135 & 45 & -135 & 45 & & -45 & 135 & -135 & 45 & -135 & 45 & \\
\hline & Solar Radiation $\left(\mathrm{W} \mathrm{m}^{-2}\right)$ & 5015.57 & 958.42 & 958.42 & 5015.57 & 2783.02 & 5593.84 & & 3727.87 & 3739.81 & 3739.81 & $\mathbf{3 7 2 7 . 8 7}$ & 7868.00 & 7928.03 & \\
\hline & Total Solar Radiation $(\mathrm{kW})$ & 124.34 & 6.51 & 115.01 & 601.87 & 483.74 & 972.31 & 2303.78 & 92.42 & 25.40 & 448.78 & 447.34 & 1367.60 & 1378.03 & 3759.57 \\
\hline \multirow{3}{*}{$\mathbf{E}$} & Azimuth angle ( $\Psi)$ & -90 & 90 & 180 & $\mathbf{0}$ & 180 & $\mathbf{0}$ & & -90 & 90 & 180 & $\mathbf{0}$ & 180 & $\mathbf{0}$ & \\
\hline & Solar Radiation $\left(\mathrm{W} \mathrm{m}^{-2}\right)$ & 2689.87 & 2689.87 & 800.22 & 6527.96 & 2078.69 & 6198.06 & & 4590.03 & 4590.03 & 2224.48 & 2210.13 & 7868.22 & 7857.77 & \\
\hline & Total Solar Radiation (kW) & 66.69 & 18.27 & 96.03 & 783.36 & 361.31 & $\mathbf{1 0 7 7 . 3 3}$ & 2402.98 & 113.79 & $\mathbf{3 1 . 1 7}$ & 266.94 & 265.22 & 1367.64 & 1365.82 & 3410.58 \\
\hline \multirow{3}{*}{ EN } & Azimuth angle $(\Psi)$ & -135 & 45 & 135 & -45 & 135 & -45 & & -135 & 45 & 135 & -45 & 135 & -45 & \\
\hline & Solar Radiation $\left(\mathrm{W} \mathrm{m}^{-2}\right)$ & 958.42 & 5015.57 & 958.42 & 5015.57 & 2783.02 & 5593.84 & & 3739.81 & 3727.87 & 3739.81 & 3727.87 & 7868.00 & 7928.03 & \\
\hline & Total Solar Radiation (kW) & 23.76 & 34.06 & 115.01 & 601.87 & 483.74 & $\mathbf{9 7 2 . 3 1}$ & 2230.75 & 92.72 & 25.32 & 448.78 & 447.34 & 1367.60 & 1378.03 & 3759.78 \\
\hline \multirow{3}{*}{$\mathbf{N}$} & Azimuth angle ( $\Psi)$ & 180 & $\mathbf{0}$ & 90 & -90 & 90 & -90 & & 180 & $\mathbf{0}$ & 90 & -90 & 90 & -90 & \\
\hline & Solar Radiation $\left(\mathbf{W ~ m}^{-2}\right)$ & 800.22 & 6527.96 & 2689.87 & 2689.87 & 4205.71 & 4205.71 & & 2224.48 & 2210.13 & 4590.03 & 4590.03 & 7939.77 & 7939.77 & \\
\hline & Total Solar Radiation (kW) & 19.84 & 44.34 & 322.78 & 322.78 & 731.03 & 731.03 & 2171.80 & 55.15 & 15.01 & 550.80 & 550.80 & 1380.07 & 1380.07 & 3931.91 \\
\hline \multirow{3}{*}{ NW } & Azimuth angle ( $\Psi)$ & 135 & -45 & 45 & -135 & 45 & -135 & & 135 & -45 & 45 & -135 & 45 & -135 & \\
\hline & Solar Radiation $\left(\mathbf{W ~ m}^{-2}\right)$ & 958.42 & $\mathbf{5 0 1 5 . 5 7}$ & $\mathbf{5 0 1 5 . 5 7}$ & 958.42 & 5593.84 & 2783.02 & & 3739.81 & 3727.87 & $\mathbf{3 7 2 7 . 8 7}$ & 3739.81 & 7928.03 & 7868.00 & \\
\hline & Total Solar Radiation (kW) & 23.76 & 34.06 & 601.87 & 115.01 & 972.31 & 483.74 & 2230.75 & 92.72 & 25.32 & 447.34 & 448.78 & 1378.03 & 1367.60 & 3759.78 \\
\hline \multirow{3}{*}{$\mathbf{W}$} & Azimuth angle ( $\Psi)$ & 90 & -90 & $\mathbf{0}$ & -180 & $\mathbf{0}$ & -180 & & 90 & -90 & $\mathbf{0}$ & -180 & $\mathbf{0}$ & -180 & \\
\hline & Solar Radiation $\left(\mathrm{W} \mathrm{m}^{-2}\right)$ & 2689.87 & 2689.87 & 6527.96 & 800.22 & 6198.06 & 2078.69 & & 4590.03 & 4590.03 & 2210.13 & 2224.48 & $\mathbf{7 8 5 7 . 7 7}$ & 7868.22 & \\
\hline & Total Solar Radiation (kW) & 66.69 & 18.27 & 783.36 & 96.03 & 1077.33 & 361.31 & 2402.98 & 113.79 & 31.17 & 265.22 & 266.94 & 1365.82 & 1367.64 & 3410.58 \\
\hline \multirow{3}{*}{ SW } & Azimuth angle $(\Psi)$ & 45 & -135 & -45 & 135 & -45 & 135 & & 45 & -135 & -45 & 135 & -45 & 135 & \\
\hline & Solar Radiation $\left(\mathrm{W} \mathrm{m}^{-2}\right)$ & 5015.57 & 958.42 & 5015.57 & 958.42 & 5593.84 & 2783.02 & & 3727.87 & 3739.81 & 3727.87 & 3739.81 & 7928.03 & 7868.00 & \\
\hline & Total Solar Radiation $(\mathbf{k W})$ & 124.34 & 6.51 & 601.87 & 115.01 & 972.31 & 483.74 & 2303.78 & 92.42 & 25.40 & 447.34 & 448.78 & 1378.03 & 1367.60 & 3759.57 \\
\hline
\end{tabular}




\section{CONCLUSION}

A model was developed for analyzing the effect of different orientations of greenhouses (most suitable for all year round applications) on the solar radiation available. With east-west (E) orientation received more solar radiation on January month and received less solar radiation on July month with small differences in received solar radiation during the two months.

\section{REFERENCES}

ASHRAE (2005) "American Society of Heating, Refrigerating, and Air Conditioning Engineers" ASHREA Handbooks, Fundamentals

Beshada, E., Zhang, Q., Boris, R., (2005) "Performance of a solar greenhouse under Manitoba's winter weather conditions" CSAESCGR - Annual Meeting, Winnipeg, Man., Canada, Paper No. 05071

Duffie, J. A., Beckman, W. A., (1991) "Solar engineering of thermal processes" 2nd ed., John Wiley and Sons, New York, USA.

Hasson, A. M., (1991) "A study of solar energy and its components under a plastic greenhouse" Energy Conversion and Management, 31,1, pp. $1-5$

Impron, I., Hemming, S., Bot, G. P. A., (2007) "Simple greenhouse climate model as a design tool for greenhouses in tropical lowland" Bio-systems Engineering, 98, 1, pp. 79-89

Kumari, N., Tiwari, G., Sodha, M., (2007) "Performance evaluation of greenhouse having passive or active heating in different climatic zones of India" Agricultural Engineering International: the CIGR Ejournal, Manuscript EE 06 011.Vol. IX

Lawrence, S. A., Tiwari, G. N., (1991) "Performance of a greenhouse cum solar still for the climatic condition of Port Moresby" Renewable Energy, 11, 2, pp. 249-255 
Pieters, J. G., Pollet, I. V., Van Put, L., (2000) "Solar energy distribution model for greenhouses" The Energy for the 21st Century World Renewable Energy Congress VI, Brighton, UK, pp. 2178-2181

Saravia, L., et al., (1997) "Greenhouse solar heating in the Argentinean northwest" Renewable Energy, 11, 1, pp. 119-128

Sethi, V. P., (2009) "On the selection of shape and orientation of a greenhouse, thermal modeling and experimental validation" Solar Energy, 83, 1, pp. 21-38

Sethi, V. P., Sharma, S. K., (2007) "Experimental and economic study of a greenhouse thermal control system using aquifer water" Energy Conversion and Management, 48, 1, pp. 306-319

Tavares, C., et al., (2001) "Modeling an agriculture production greenhouse" Renewable Energy, 22, 1-3, pp. 15-20

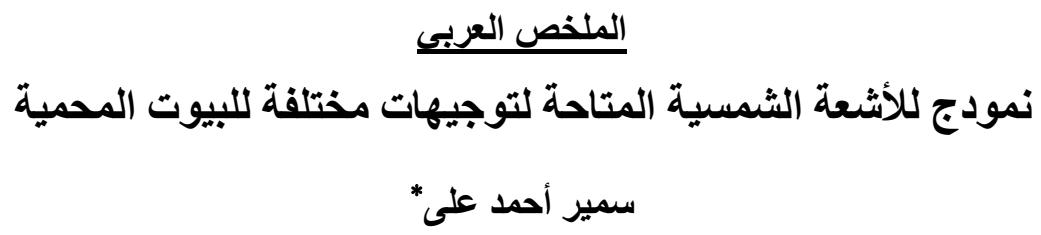

الهدف الرئيسى من إنشاء البيوت المحمية هو تحسين الظروف المناخية لنمو و إنتاجية النباتات

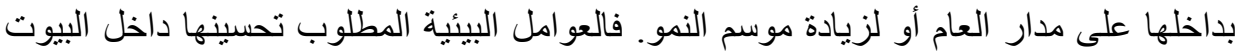
المحمية تنوقف على عدة عوامل، منها مدة وكمية الإشعاع الثمسي الو اقع على تلك اليبوت.

لذلك كان الهدف من هذه الدراسة هو عمل نموذج على الحاسب الآلي باستخدام MS Excel

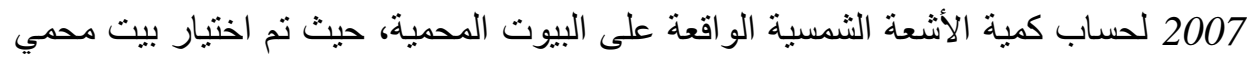

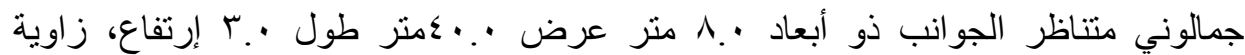

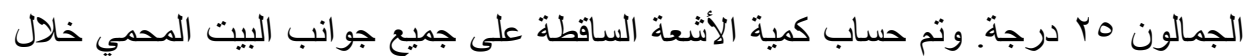

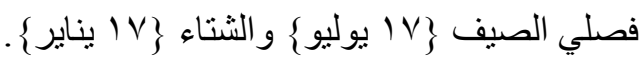

* أستاذ الهندة الزراعية المساعد كلية الزراعة بمشتهر جامعة بنها 
تم تجريب النموذج بافتر اض أن البيت المحمي مقام بكلية الزراعة بمشتهر بمدينة طوخ محافظة

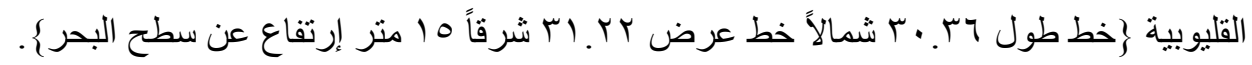

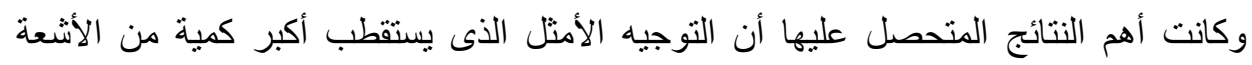

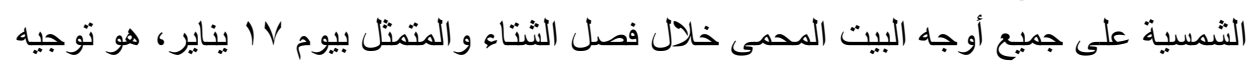

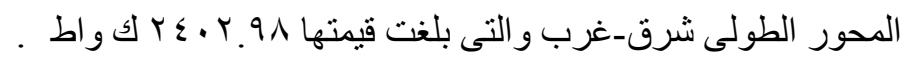

تم عمل إختبار صلاحية للنموذج بمقارنة نتائجه بالبيانات المتحصل عليها من محطة الأرصاد

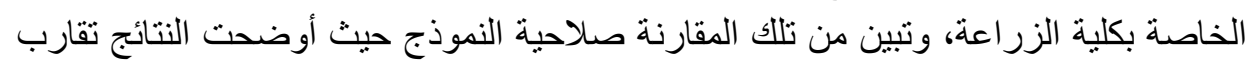

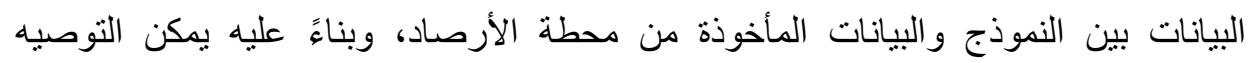
باستخدامه لمعرفة التوجيه الأمثل للبيوت المحمية في الأماكن المختلفة. 